\title{
What is the contribution of each physical activity domain to total physical activity in adolescents?
}

\section{Qual a contribuicão de cada domínio da atividade física para atividade fisica total em adolescentes?}

Josiene de Oliveira Couto ${ }^{1}$

(D) https://orcid.org/0000-0002-1328-6859

Raphael Henrique Oliveira Araujo ${ }^{1}$

(1D) https://orcid.org/0000-0002-9405-3052

Ellen Caroline Mendes da Silva ${ }^{\top}$

(1D) https://orcid.org/0000-0001-9856-0054

Nara Michelle Moura Soares 1,2

(1) https://orcid.org/0000-0001-9910-1730

Antonio Evaldo dos Santos ${ }^{1}$

(10) https://orcid.org/0000-0001-8837-0329

Roberto Jerônimo dos Santos Silva ${ }^{1}$

(D) https://orcid.org/0000-0002-4578-7666

Abstract - The present study aimed to verify the contribution of different physical activity domains to "total physical activity" in Brazilian adolescents. This is a cross-sectional study using secondary data from the third edition of the National School Health Survey - PeNSE, 2015. The sample consisted of 100,497 adolescents of both sexes enrolled in the $9^{\text {th }}$ grade of elementary schools. A linear regression model was used to verify how much each domain contributed to total physical activity, considering gender, type of municipality and region. The domain with the largest contribution to "total physical activity" regardless of sociodemographic and environmental variables was "extra-school physical activity" $(\mathrm{R} 2=0.60)$, followed by "active commuting" $(\mathrm{R} 2=0.34)$, and finally "Physical Education classes" $(\mathrm{R} 2=0.23)$. The contribution of the different domains varied by gender, type of municipality and region, and it was concluded that "extra-school physical activity" make the greatest contribution to "total physical activity", followed by "active commuting" and "Physical Education classes". In addition, variation was observed in the contribution of domains by gender, type of municipality and region.

Key words: Adolescent behavior; Physical activity; Physical Education.

Resumo - O presente estudo teve como objetivo verificar a contribuição dos diferentes dominios da atividade física na "atividade física total" em adolescentes brasileiros. Trata-se de estudo transversal utilizando dados secundários oriundos da terceira edição da Pesquisa Nacional de Saúde do Escolar - PeNSE, 2015. A amostra foi constituída por 100.497 adolescentes de ambos os sexos cursando o $9^{\circ}$ ano do Ensino Fundamental. Utilizou-se um modelo de regressão linear a fim de averiguar o quanto cada dominio contribuiu para a atividade física total, considerando o sexo, tipo de município e região. O dominio que apresentou maior contribuição para "atividade física total" independentemente das variáveis sociodemográficas e ambientais foram as "atividades físicas extraescolares" $\left(R^{2}=0,60\right)$, seguido do "deslocamento ativo" $\left(R^{2}=0,34\right)$, e por fim as "aulas de Educação Física" $\left(R^{2}=0,23\right)$. A contribuição dos diferentes dominios apresentou variaçôes por sexo, tipo de município e região. Conclui-se que as "atividades extraescolares" apresentam a maior contribuição para a "atividade física total", seguido do "deslocamento ativo" e das "aulas de Educação Física". Além disso, verifica-se uma variação na contribuição dos dominios por sexo, tipo de município e região.

Palavras-chave: Atividade física; Comportamento do adolescente; Educação física.
1 Federal University of Sergipe. Graduate Program in Physical Education. São Cristóvão, SE. Brazil.

2 Tiradentes University. Aracaju SE. Brazil

Received: November 21, 2019 Accepted: March 03, 2020

How to cite this article Couto JO, Araujo RHO, Silva ECM, Soares NMM, Santos AE, Silva RJS What is the contribution of each physical activity domain to total physical activity in adolescents? Rev Bras Cineantropom Desempenho Hum 2020, 22:e70170. DOl: http://dx.doi.org/10.1590/19800037.2020v22e70170

Copyright: This work is licensed under a Creative Commons Attribution 4.0 International License. 


\section{INTRODUCTION}

The regular practice of physical activity provides health improvements and acts preventing diseases at all stages of life ${ }^{1,2}$. In adolescence, the adoption of an active lifestyle can estimate the involvement in physical activity in adulthood ${ }^{3}$.

Despite this evidence, it appears that between 11 and 17 years of age, regardless of country, less than $20 \%$ of adolescents meet the recommendations of 60 daily minutes of physical activity ${ }^{4}$, however, when analyzing data from Brazil, a prevalence of $30.7 \%$ is estimated ${ }^{5}$.

Aiming at increasing the level of physical activity in adolescents, action plans were developed considering the different physical activity domains (leisure, work / school, domestic and commuting) and the context in which they are and can be developed ${ }^{4}$. In this sense, the different domains in which adolescents will engage may make different contributions to total physical activity.

In adolescence, actions and investigations have shown that the main focus is Physical Education classes ${ }^{6}$, extra-school physical activity ${ }^{7}$ and active commuting ${ }^{8}$, since there is greater engagement in these domains during this phase of life. However, it is observed that there is variation in the time spent among these domains ${ }^{9}$, indicating the need to verify the contribution of each of these in total physical activity in adolescents.

In this sense, understanding the contribution of the different domains that make up the total physical activity construct is essential for the development of interventions in which behavior change is one of the concerns, in a more responsive way, considering the needs of adolescents. In addition, there are few studies addressing these domains together during adolescence ${ }^{10}$.

Given the above, the present study aimed to verify the contribution of different physical activity domains to total physical activity in Brazilian adolescents.

\section{METHOD}

\section{Study Design}

This is a cross-sectional study using secondary data from the third edition of the National School Health Survey - PeNSE, 2015. This edition was developed between April and September 2015 in order to identify risk factors and health protection of Brazilian adolescents regularly attending school in the day shift ${ }^{11,12}$.

This study used data referring to the sample named "number one" of PeNSE, 2015. This sample consists of representative data of Brazilian adolescents enrolled in the $9^{\text {th }}$ grade of elementary school in $2015^{11,12}$. Fifty-three geographic strata were used, consisting of capitals and noncapital municipalities of each Federation Unit. In capitals, school and class sampling units were used; however, in non-capital municipalities, in 
addition to these, the IBGE agency was added ${ }^{11,12}$.

PeNSE 2015 was approved by the National Research Ethics Commitee - Conep No. 1.006.467, of 03/30/2015.

\section{Participants}

The survey was conducted with 3040 schools, 4159 classes and 102,301 students answered the survey questionnaire ${ }^{11}$. All students present in the selected classes were invited to participate in the research, but only those who agreed with the Free and Informed Consent Term, participated in the research ${ }^{11}$.

\section{Instruments}

Data were collected using an electronic questionnaire and the Personal Digital Assistant (PDA). To complete the questionnaire, students were instructed to consider the last seven days prior to the survey. Further information on PeNSE and its methodological aspects can be obtained from previous publication ${ }^{11,12}$.

\section{Variables}

For "active commuting", the average daily time accumulated by the student was used, with commuting to and from school on foot or bicycle. For physical activities performed in "Physical Education classes", the accumulated average duration in which the student practiced physical activity or sport during the period of Physical Education classes at school was used. For "extra-school physical activity", the average daily time accumulated by the student with some physical activity performed during the extra-school period was considered. "Total physical activity" was estimated based on the product between the number of days and the average time spent by students in physical activities in commuting, physical education classes and extra-school physical activity domains, considering the seven days prior to the survey ${ }^{11}$.

Sociodemographic (gender, age and race) and environmental (type of municipality, regions and study shift) variables were used. The characterization and cutoff points of variables used are presented in Box 1.

\section{Statistical analysis}

For data interpretation, descriptive analysis and confidence interval (95\% CI) were used. Linear regression model was used to verify how much each domain contributed to "total physical activity", considering gender, type of municipality and region. Data are presented with their respective determination coefficient, beta estimator and confidence interval values, and throughout the analysis, 5\% significance level ( $\mathrm{p} \leq 0.05)$ was considered. In all analyses, sample weights were used as weighting procedure considering instructions available for the PeNSE 2015 survey. Statistical treatment was performed using STATA version 15.0 software. 
Box 1. Characterization and cutoff points of variables used in this study

\begin{tabular}{|c|c|c|}
\hline Variables & Categorization & Criterion / Characterization \\
\hline \multirow{2}{*}{ Gender $^{\mathrm{a}}$} & Female & \multirow{2}{*}{ Biological Classification } \\
\hline & Male & \\
\hline \multirow{2}{*}{ Age group ${ }^{b}$} & $\leq 14$ years & \multirow{2}{*}{ Distribution Median } \\
\hline & $>14$ years & \\
\hline \multirow{2}{*}{ Race/Color } & Non white & Race / Color: black, yellow, brown and indigenous \\
\hline & White & All white \\
\hline \multirow{5}{*}{ Regions } & Northern & \multirow{5}{*}{ Federation Units groups } \\
\hline & Northeastern & \\
\hline & Southeastern & \\
\hline & Southern & \\
\hline & Mid-western & \\
\hline \multirow{2}{*}{ Type of Municipality } & Non capital & \multirow{2}{*}{ Location } \\
\hline & Capital & \\
\hline \multirow{2}{*}{ Study shift ${ }^{d}$} & Part time & \multirow{2}{*}{$\begin{array}{l}\text { Graded according to length of school stay "Part time" consid- } \\
\text { ered morning or afternoon; "Full time" only full time }\end{array}$} \\
\hline & Full time & \\
\hline Total Physical Activity Time & Continuous Data & In Minutes \\
\hline Active commuting & Continuous Data & In Minutes \\
\hline $\begin{array}{l}\text { Physical activity in physical educa- } \\
\text { tion classes }\end{array}$ & Continuous Data & In Minutes \\
\hline Extra-School Physical Activity & Continuous Data & In Minutes \\
\hline
\end{tabular}

Note: a Question VB01001; ' Question VB01003; ' Question VB01002; d Question VB01022

\section{RESULTS}

A total of 102,301 adolescents were interviewed, but 1.804 were excluded due to the lack of important information such as age and / or gender, in addition to data from those who did not attend the 9 th grade of elementary school, resulting in a sample with 100,497 participants.

The sample consisted of adolescents of both sexes, mostly composed of females aged " $\leq 14$ years", "non-white", living in capitals and studying in a "part time" system (Table 1).

The domain that made the greatest contribution to "total physical activity" was "extra-school physical activity", followed by "active commuting" and "physical education classes", respectively (Table 2).

Table 3 shows the contribution of "extra-school physical activity" to the total physical activity of adolescents. For female adolescents living in capitals, "total physical activity" was best explained by "extra-school physical activity" in the Mid-western region, with $56 \%\left(\mathrm{R}^{2}=0.56\right)$, followed by the Southern region, with $54 \%\left(\mathrm{R}^{2}=0.54\right)$. However, for those who do not live in capitals, this domain presented the largest contribution in the Southern region, with $60 \%\left(\mathrm{R}^{2}=0.60\right)$, followed by the Northern region, with $53 \%\left(\mathrm{R}^{2}=0.53\right)$.

Regarding males, regardless of type of municipality, the largest contribution of "extra-school physical activity" to total physical activity occurred in the Southern region, with $67 \%\left(\mathrm{R}^{2}=0.67\right)$ and $68 \%\left(\mathrm{R}^{2}=0.68\right)$ for "capital" and "non-capital", respectively. 
Table 1. Characteristics of sample participants.

\begin{tabular}{llll}
\hline Variables & $\mathrm{N}$ & $\%$ & $95 \% \mathrm{Cl}$ \\
\hline Gender & & & \\
\hline Female & 51.998 & 51.7 & $41.4-52.1$ \\
\hline Male & 48.499 & 48.3 & \\
Age group & & & $67.9-48.6$ \\
$\leq 14$ years & 68.097 & 67.8 & $32.0-32.5$ \\
\hline 14 years & 32.400 & 32.2 & $66.5-67.1$ \\
\hline Race/Color & & & $32.9-33.5$ \\
\hline Non white & 67.034 & 66.8 & \\
\hline White & 33.359 & 33.2 & $49.5-50.1$ \\
\hline Type of municipality & & & $49.9-50.5$ \\
\hline Non capital & 50.055 & 49.8 & \\
\hline Capital & 50.442 & 50.2 & $98.2-98.4$ \\
\hline Study shift & & & $1.6-1.8$ \\
\hline Part time & 98.544 & 98.3 & \\
\hline Full time & 1.718 & 1.7 & \\
\hline
\end{tabular}

Note: $95 \% \mathrm{Cl}=$ confidence interval

Table 2. Contribution of different physical activity domains to total physical activity.

\begin{tabular}{lcccc}
\hline Variables & $\mathrm{R}^{2}$ & $\mathrm{P}$ & $\mathrm{B}$ & $\mathrm{Cl}(95 \%)$ \\
\hline Extra-school physical activity & 0.60 & $<0.001$ & 1.12 & $1.11-1.13$ \\
Active commuting & 0.34 & $<0.001$ & 1.06 & $1.04-1.08$ \\
Physical education classes & 0.23 & $<0.001$ & 1.70 & $1.65-1.75$ \\
\hline
\end{tabular}

Note: $\mathrm{R} 2$ = determination coefficient; $\mathrm{B}$ = estimator $\mathrm{B} ; 95 \% \mathrm{Cl}=$ confidence interval

Table 3. Contribution of "extra-school physical activity" to "total physical activity" in Brazilian adolescents, 2015

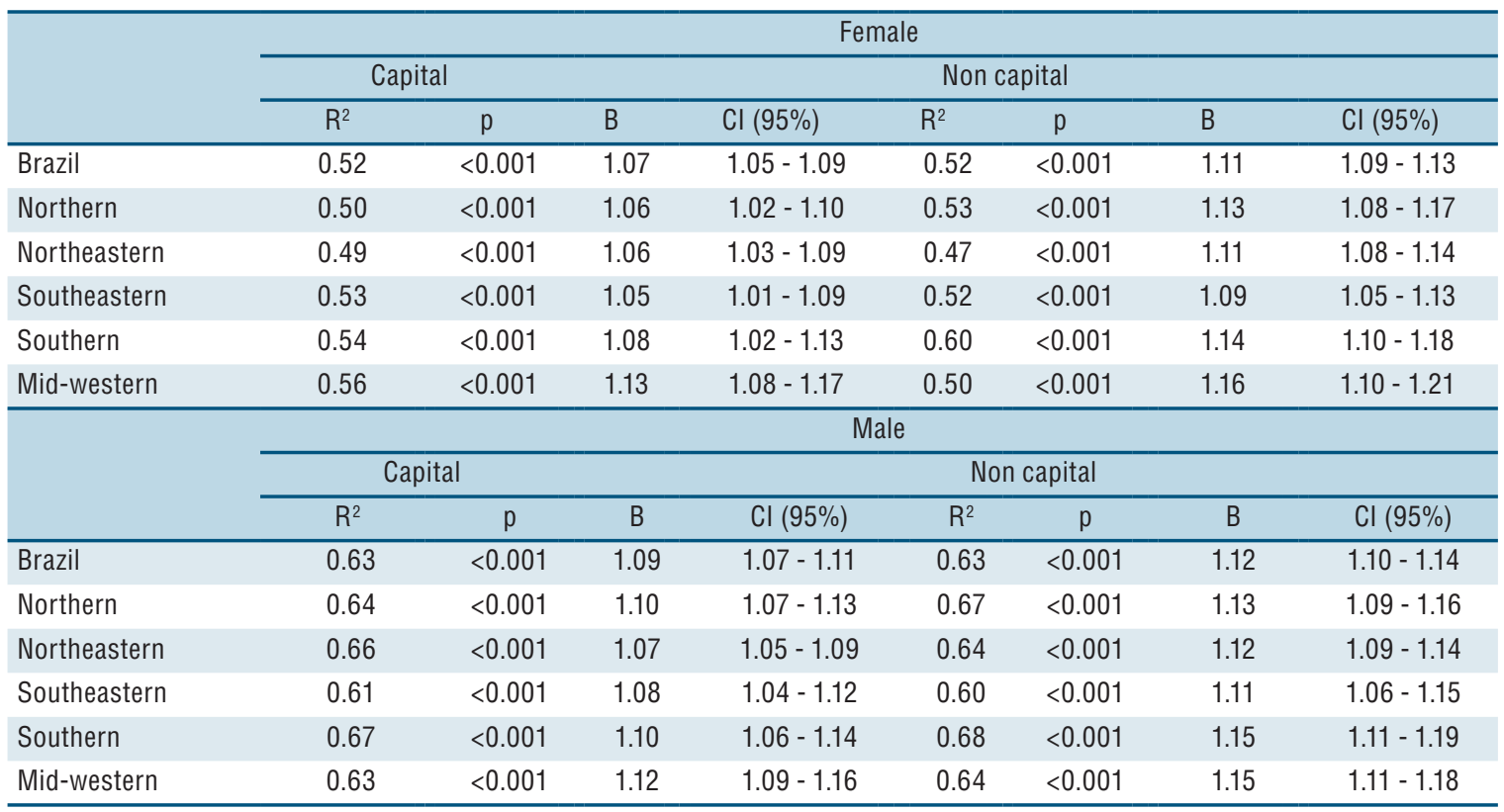

Note: $\mathrm{R} 2$ = determination coefficient; $\mathrm{B}$ = estimator $\mathrm{B} ; 95 \% \mathrm{Cl}$ = confidence interval

Table 4 presents the contribution of "active commuting" to "total physical activity" in adolescents. For female adolescents living in capitals, 
the largest contribution of "active commuting" to "total physical activity" was found in the Northern region, with $42 \%\left(\mathrm{R}^{2}=0.42\right)$, followed by the Northeast region, with $41 \%\left(\mathrm{R}^{2}=0.41\right)$. However, regarding those who did not live in capitals, this contribution was higher in the Northeastern region, with $49 \%\left(\mathrm{R}^{2}=0.49\right)$, followed by the Mid-western region, with $48 \%\left(\mathrm{R}^{2}=0.48\right)$.

Considering male adolescents living in capitals, the contribution of "active commuting" to "total physical activity" was higher in the Southeast region, with $34 \%\left(\mathrm{R}^{2}=0.34\right)$; however, for those who did not live in capitals, the largest contribution was in the Southern region, with $35 \%\left(\mathrm{R}^{2}=0.35\right)$.

Table 4. Contribution of "active commuting" to "total physical activity" in Brazilian adolescents, 2015.

\begin{tabular}{|c|c|c|c|c|c|c|c|c|}
\hline & \multicolumn{8}{|c|}{ Female } \\
\hline & \multicolumn{2}{|c|}{ Capital } & \multicolumn{6}{|c|}{ Non capital } \\
\hline & $\mathrm{R}^{2}$ & $p$ & $B$ & $\mathrm{Cl}(95 \%)$ & $\mathrm{R}^{2}$ & $p$ & $B$ & $\mathrm{Cl}(95 \%)$ \\
\hline Brazil & 0.37 & $<0.001$ & 0.96 & $0.93-0.99$ & 0.42 & $<0.001$ & 1.03 & $1.01-1.05$ \\
\hline Northern & 0.42 & $<0.001$ & 1.00 & $0.95-1.05$ & 0.46 & $<0.001$ & 1.09 & $1.04-1.15$ \\
\hline Northeastern & 0.41 & $<0.001$ & 0.96 & $0.92-0.99$ & 0.49 & $<0.001$ & 1.04 & $1.01-1.06$ \\
\hline Southeastern & 0.34 & $<0.001$ & 0.94 & $0.89-1.00$ & 0.38 & $<0.001$ & 0.99 & $0.95-1.03$ \\
\hline Southern & 0.33 & $<0.001$ & 0.96 & $0.86-1.06$ & 0.35 & $<0.001$ & 1.08 & $1.01-1.15$ \\
\hline \multirow[t]{4}{*}{ Mid-western } & 0.36 & $<0.001$ & 1.04 & $0.97-1.11$ & 0.48 & $<0.001$ & 1.10 & $1.04-1.16$ \\
\hline & \multicolumn{8}{|c|}{ Male } \\
\hline & \multicolumn{2}{|c|}{ Capital } & \multicolumn{6}{|c|}{ Non capital } \\
\hline & $\mathrm{R}^{2}$ & $p$ & B & $\mathrm{Cl}(95 \%)$ & $\mathrm{R}^{2}$ & $p$ & $B$ & $\mathrm{Cl}(95 \%)$ \\
\hline Brazil & 0.31 & $<0.001$ & 1.08 & $1.04-1.11$ & 0.33 & $<0.001$ & 1.13 & $1.08-1.17$ \\
\hline Northern & 0.31 & $<0.001$ & 1.06 & $1.00-1.12$ & 0.30 & $<0.001$ & 1.16 & $1.09-1.23$ \\
\hline Northeastern & 0.26 & $<0.001$ & 1.01 & $0.96-1.07$ & 0.33 & $<0.001$ & 1.14 & $1.09-1.19$ \\
\hline Southeastern & 0.34 & $<0.001$ & 1.10 & $1.04-1.17$ & 0.32 & $<0.001$ & 1.09 & $1.00-1.17$ \\
\hline Southern & 0.30 & $<0.001$ & 1.07 & $0.99-1.15$ & 0.35 & $<0.001$ & 1.20 & $1.12-1.28$ \\
\hline Mid-western & 0.31 & $<0.001$ & 1.10 & $1.03-1.17$ & 0.34 & $<0.001$ & 1.13 & $1.05-1.21$ \\
\hline
\end{tabular}

Note: $\mathrm{R} 2$ = determination coefficient; $\mathrm{B}=$ estimator $\mathrm{B} ; 95 \% \mathrm{Cl}=$ confidence interval

Table 5 presents the contribution of "Physical Education classes" to "total physical activity" in adolescents. It was found that for female adolescents, regardless of type of municipality, the largest contribution of "Physical Education classes" to "total physical activity" occurred in the Southern region, with $23 \%\left(R^{2}=0.23\right)$ and $24 \%\left(R^{2}=0.24\right)$ for "capital" and "non-capital", respectively. Considering males living in capitals, the region in which "Physical Education classes" best explained "total physical activity" was the Mid-western region, with $25 \%\left(\mathrm{R}^{2}=0.25\right)$; however, for those who do not live in capitals, this domain presented greater explanation in the Southeast region, with $26 \%\left(\mathrm{R}^{2}=0.26\right)$.

\section{DISCUSSION}

As the main result, it was found that the degree of contribution of physical 
Table 5. Contribution of "Physical Education classes" to "total physical activity" in Brazilian adolescents, 2015.

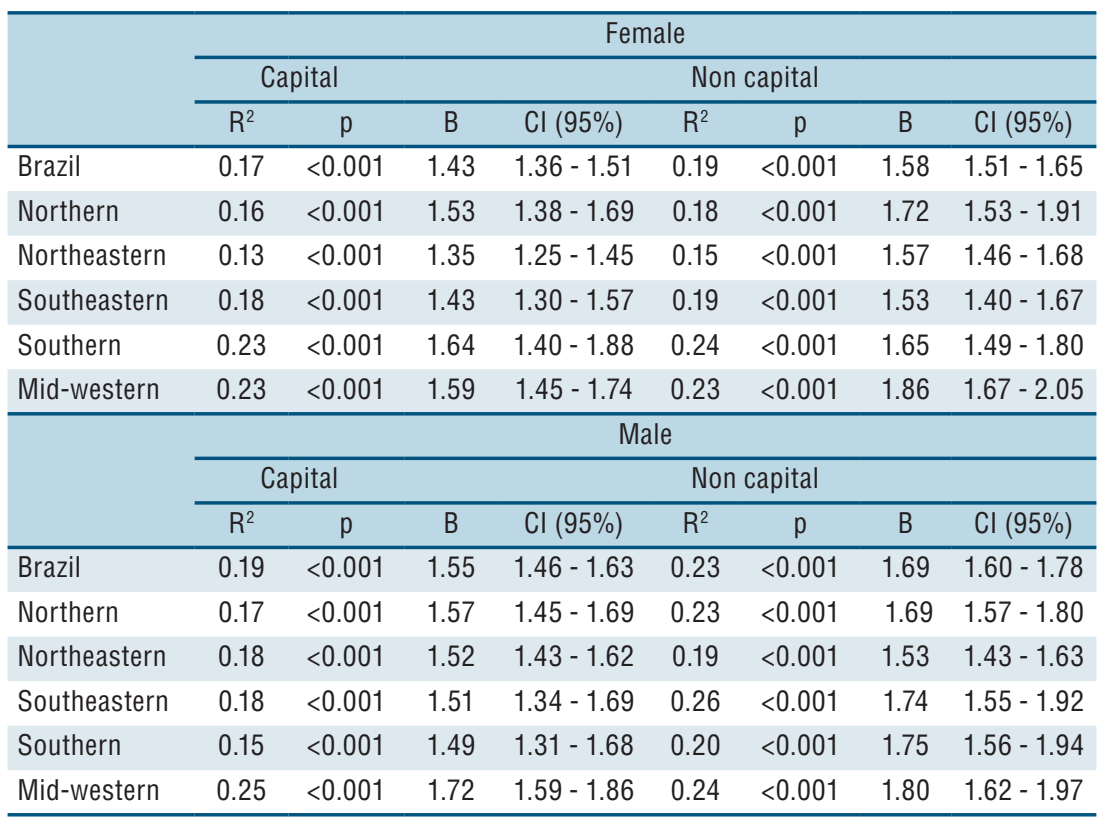

Note: $\mathrm{R} 2$ = determination coefficient; $\mathrm{B}=$ estimator $\mathrm{B} ; 95 \% \mathrm{Cl}=$ confidence interval

activity domains to "total physical activity", regardless of gender, type of municipality and region, were, respectively, "extra-school physical activity", "active commuting" and "Physical Education classes".

There is agreement between results of the present study and data obtained from PeNSE 2012, in which "extra-school physical activity" made the largest contribution to "total physical activity", followed by "active commuting" and "Physical Education classes"

Regarding "extra-school physical activity", it was found that for female adolescents living in capitals, this domain had the greatest contribution to "total physical activity" in the Midwestern region, however, for those who did not live in capitals, the greatest contribution occurred in the Southern region. For males, regardless of type of municipality, "extra-school physical activity" made the largest contribution to "total physical activity" in the Southern region.

One possible explanation for the greater engagement in "extra-school physical activity" in adolescents is their autonomy in choosing the activity to engage in ${ }^{13}$ and the social support offered, especially by friends, for involvement in extra-school physical activities ${ }^{14}$.

The result of the present study corroborates with previous study ${ }^{15}$ in which there was greater contribution of extra-school sports practice to "total physical activity". Similarly, study ${ }^{9}$ found that during weekdays, adolescents had higher energy expenditure in sports practiced in the extra-school period. Study ${ }^{16}$ found that the practice of "extra-school physical activity" may be a strong predictor of subsequent practice over the years.

For female and male participants living in capitals, "active commuting" made the largest contribution to "total physical activity", respectively, in 
the Northern and Southeastern regions. However, when considering those who do not live in capitals, this domain made the largest contribution to "total physical activity" in the Northeastern and Southern regions for females and males, respectively. These findings are compatible with previous study ${ }^{8}$, who identified the mode of "active commuting" to school as a correlate of levels of physical activity for both sexes. In contrast, Smith, Aggio, Hamer ${ }^{17}$ did not identify association between type of commuting and levels of physical activity.

One aspect that should be considered is that, depending on the region of the country, "active commuting" is a compulsory activity, in which sociodemographic and environmental factors can be considered determinant for its practice ${ }^{8,18}$.

Regarding "Physical Education classes" domain, it was found that adolescents of both sexes and living in capitals presented higher values in the Mid-western region compared to the other regions, indicating greater contribution of this domain to the "total physical activity" accumulation. However, for those who do not live in capitals, the "Physical Education classes" domain made the largest contribution to "total physical activity" for females in the Mid-western region and for males in the Southeastern region. These findings can be explained by the variation in the number of Physical Education classes offered in the different regions, considering that regions with the highest economic development have the highest number of Physical Education classes and greater involvement in physical activity during this period ${ }^{19}$.

In this sense, study ${ }^{20}$ observed that the greater the offer of Physical Education classes, the greater the involvement of students in moderate to vigorous physical activities throughout the day. Similarly, previous studies have found that, on the days when Physical Education classes are offered, increase in levels of physical activities is observed, and the largest increase in these levels occurred mainly in inactive students ${ }^{19,21}$.

The limitation presented by this study is that the amount of practice in each physical activity domain was self-reported, thus, values may be overestimated or underestimated and may not express the real values of their practice. However, studies have been conducted using subjective methods and the methodological rigor adopted increased the reliability of information collected. As strength, the study has representative sample size and information obtained can be extrapolated, ensuring its internal and external validity.

\section{CONCLUSION}

It could be concluded that "extra-school physical activity" make the greatest contribution to "total physical activity", followed by "active commuting" and "Physical Education classes". In addition, variation was observed in the contribution of domains by gender, type of municipality and region. 


\section{Acknowledgments}

We would like to thank the Brazilian Institute of Geography and Statistics for data collection, as well as CAPES for funding Couto, JO and Araujo, RHO.

\section{COMPLIANCE WITH ETHICAL STANDARDS}

\section{Funding}

Coordination for Improvement of Higher Education Personnel (CAPES) agency.

\section{Ethical approval}

Ethical approval was obtained from the local Human Research Ethics Committee - Conep and the protocol (no. 1.006.467) was written in accordance with the standards set by the Declaration of Helsinki.

\section{Conflict of interest statement}

The authors have no conflict of interests to declare.

\section{Author Contributions}

Conceived and designed the study: JOC, RHOA, RJSS. Performed the experiments: JOC, RHOA, RJSS. Analyzed the data: JOC, RHOA, RJSS. Contributed reagents/materials/analysis tools: JOC, RHOA, ECMS, NMMS, AES, RJSS. Wrote the paper: JOC, RHOA, ECMS, NMMS, AES, RJSS.

\section{REFERENCES}

1. Granger E, Di Nardo F, Harrison A, Patterson L, Holmes R, Verma A. A systematic review of the relationship of physical activity and health status in adolescents. Eur J Public Health 2017;27(2):100-6.

2. Kyu HH, Bachman VF, Alexander LT, Mumford JE, Afshin A, Estep K, et al. Physical activity and risk of breast cancer, colon cancer, diabetes, ischemic heart disease, and ischemic stroke events: Systematic review and dose-response metaanalysis for the Global Burden of Disease Study 2013. BMJ 2016;354:1-10.

3. Telama R, Yang X, Viikari J, Välimäki I, Wanne O, Raitakari O. Physical activity from childhood to adulthood: A 21-year tracking study. Am J Prev Med. 2005;28(3):267-73.

4. World Health Organization. Global Action Plan on Physical Activity 2018 2030. 2018

5. Silva DAS, Christofaro DGD, Ferrari GL, Silva KS, Nardo N Jr, Silva RJS, et al. Resultados do Boletim Brasileiro de 2018 sobre atividade física para crianças e jovens. J Phys Act Health 2018;15(2):323-25.

6. Lonsdale C, Rosenkranz RR, Peralta LR, Bennie A, Fahey P, Lubans DR. A systematic review and meta-analysis of interventions designed to increase moderate-to-vigorous physical activity in school physical education lessons. Prev Med 2013;56(2):152-61.

7. Beets MW, Weaver RG, Turner-Mcgrievy G, Huberty J, Ward DS, Pate RR, et al. Making policy practice in afterschool programs: A randomized controlled trial on physical activity changes. Am J Prev Med 2015;48(6):694-706.

8. Pizarro AN, Schipperijn J, Andersen HB, Ribeiro JC, Mota J, Santos MP. Active commuting to school in Portuguese adolescents: Using PALMS to detect trips. J Transp Health 2016;3(3):297-304. 
9. Slingerland M, Borghouts LB, Hesselink MKC. Physical Activity Energy Expenditure in Dutch Adolescents: Contribution of Active Transport to School, Physical Education, and Leisure Time Activities. J Sch Health 2012;82(5):225-32.

10. De Rezende LFM, Azeredo CM, Canella DS, Claro RM, De Castro IRR, Levy $\mathrm{RB}$, et al. Sociodemographic and behavioral factors associated with physical activity in Brazilian adolescents. BMC Public Health 2014;14(1):1-11.

11. Instituto Brasileiro de Geografia e Estatística (IBGE). Pesquisa Nacional de Saúde Do Escolar (PeNSE) 2015. IBGE. 2016.16.

12. Oliveira MM, Campos MO, Andreazzi MAR, Malta DC. Características da Pesquisa Nacional de Saúde do Escolar - PeNSE. Epidemiol Serv Saúde 2017;26(3):605-16.

13. James M, Todd C, Scott S, Stratton G, McCoubrey S, Christian D, et al. Teenage recommendations to improve physical activity for their age group: A qualitative study. BMC Public Health. 2018;18(1):1-9.

14. Silva M, Engers P, Vilela G, Spohr C, Rombaldi A. Fontes de informação sobre benefícios à prática de atividade física e fatores associados em adolescentes: estudo de base escolar. Rev Bras Ativ Fís Saúde 2016;21(3):237-45.

15. Smith MP, Berdel D, Nowak D, Heinrich J, Schulz H. Physical activity levels and domains assessed by accelerometry in German adolescents from GINIplus and LISAplus. PLoS One 2016;11(3):1-17.

16. Hardie Murphy M, Rowe DA, Woods CB. Impact of physical activity domains on subsequent physical activity in youth: a 5-year longitudinal study. J Sports Sci 2017;35(3):262-8.

17. Smith L, Aggio D, Hamer M. Active travel to non-school destinations but not to school is associated with higher physical activity levels in an ethnically diverse sample of inner-city schoolchildren. BMC Public Health 2017;17(1):1-6.

18. Larouche R, Sarmiento OL, Broyles ST, Denstel KD, Church TS, Barreira T $\mathrm{V}$, et al. Are the correlates of active school transport context-specific? Int J Obes 2015;5(S2):S89-99.

19. Silva DAS, Chaput JP, Tremblay MS. Participation frequency in physical education classes and physical activity and sitting time in Brazilian adolescents. PLoS One 2019;14(3):1-14.

20. Meyer U, Roth R, Zahner L, Gerber M, Puder JJ, Hebestreit H, et al. Contribution of physical education to overall physical activity. Scand J Med Sci Sport 2011;23(5):600-6.

21. Aljuhani O, Sandercock G. Contribution of Physical Education to the Daily Physical Activity of Schoolchildren in Saudi Arabia. Int J Environ Res Public Health 2019;16(13):2397.

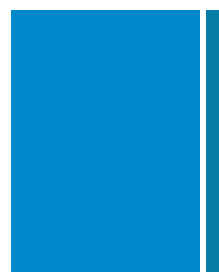

Corresponding author

Roberto Jerônimo dos Santos Silva

Graduate Program in Physical Education

Department of Physical Education

Federal University of Sergipe, São Cristóvão, Brazil.

Av. Marechal Rondon s/n

CEP: 49.100-000

Email: rjeronimoss@gmail.com 